\title{
IMPLEMENTASI ALGORITMA FAST (FEATURES FROM ACCELERATED SEGMENT TEST) CORNER DETECTOR UNTUK PENGENALAN ALAT MUSIK TRADISIONAL KABUPATEN KUNINGAN BERBASIS AUGMENTED REALITY
}

\author{
Rio Priantama ${ }^{1}$, Agus Wahyudin ${ }^{2}$, Hendra Wibowo ${ }^{3}$ \\ ${ }^{123}$ Teknik Informatika Fakultas Ilmu Komputer Universitas Kuningan \\ ${ }^{123} \mathrm{~J}$ In. Cut Nyak Dhien No.36A, Cijoho, Kuningan, Jawa Barat 45513 \\ E-mail: ${ }^{1}$ rio.priantama@uniku.ac.id, ${ }^{2}$ agus.wahyudin@uniku.ac.id, ${ }^{3}$ hendra@gmail.com
}

\begin{abstract}
Abstrak
Salah satu kebudayaan Kabupaten Kuningan yang masih ada hingga saat adalah alat musik tradisional yang jumlah dan jenis, informasi sejarah serta cara memainkan semakin langka untuk diperkenalkan di sekolah-sekolah dan sanggar-sanggar. Salah satu upaya melestarikan dan memperkenalkan alat musik tradisional di Kabupaten Kuningan kepada masyarakat, adalah dengan menggelar festival-festival alat musik tradisional tahunan, namun upaya tersebut belum mampu untuk meningkatkan pengetahuan masyarakat mengenai informasi dari alat musik tradisional yang ada di Kabupaten Kuningan. Teknologi yang mampu memberikan informasi alat musik tradisional serta mampu menarik dan bersifat interaktif mutlak diperlukan sebagai upaya alternatif. Aplikasi Augmented Reality dengan mengimplementasikan algoritma FAST Corner Detector dapat dibangun sebagai alternatif pengenalan alat musik tradisional yang ada di Kabupaten Kuningan. Aplikasi ini dibangun dengan menggunakan metode pengembangan sistem RUP (Rational Unified Process). Aplikasi Augmented Reality Pengenalan Alat Musik Tradisional Kabupaten Kuningan ini dapat memberikan informasi tentang jenis alat musik serta contoh suara dan video tentang cara memainkan alat musik tradisional sebagai sarana media dalam upaya melestarikan alat musik tradisional kabupaten Kuningan pada masyarakat khususnya generasi muda.
\end{abstract}

Kata Kunci : : Augmented Reality, FAST Corner Detector, Rational Unified Process, Alat Musik Tradisional

\begin{abstract}
One of the cultures of Kuningan Regency that still exists today is traditional musical instruments whose numbers and types, historical information and how to play are increasingly rare to be introduced in schools and studios. One of the efforts to preserve and introduce traditional musical instruments in Kuningan Regency to the community, is by holding annual traditional musical instrument festivals, but these efforts have not been able to increase public knowledge about information from traditional musical instruments in Kuningan Regency. Technology that is able to provide information on traditional musical instruments and is able to be attractive and interactive is absolutely necessary as an alternative effort. Augmented Reality application by implementing the FAST Corner Detector algorithm can be built as an alternative to the introduction of traditional musical instruments in Kuningan Regency. This application was built using the RUP (Rational Unified Process) system development method. Application of Augmented Reality Introduction to Traditional Musical Instruments in Kuningan Regency can provide information about the types of musical instruments as well as examples of sounds and videos on how to play
\end{abstract}


traditional musical instruments as a means of media in an effort to preserve traditional musical instruments in Kuningan regency in society, especially the younger generation.

Keywords : Augmented Reality, FAST Corner Detector, Rational Unified Process,Traditional musical instrumen

\section{PENDAHULUAN}

Letak geografis kuningan yang berada di bawah kaki gunung Ciremai dan berbatasan dengan beberapa kabupaten di sekitarnya, menjadikan Kuningan memiliki kekayaan alam dan budaya yang beraneka ragam. Terutama di bidang seni budaya, beberapa seni budaya asli berasal dari Kabupaten Kuningan ini, baik itu upacara adat, tarian tradisional, alat musik tradisional, dan lain sebagainya

Alat musik tradisional sebagai salah satu warisan budaya adalah alat-alat musik yang berkembang secara turuntemurun pada suatu daerah yang digunakan untuk mengiringi lagu-lagu daerah asal berkembangnya alat musik tersebut. Kabupaten Kuningan memiliki beberapa alat musik tradisional tersebut, seperti angklung, calung, suling, dan lain sebagainya. Saat ini, keberadaan alat-alat musik tradisonal khas kabupaten Kuningan semakin langka ketersediannya dan tidak semua sekolah dan sanggar memiliki alat musik tradisional yang sama dengan sekolah dan sanggar yang lain.

Berbagai cara dilakukan dari pihak Dinas Pendidikan dan Kebudayaan Kabupaten Kuningan sebagai upaya melestarikan dan memperkenalkan alat musik tradisional Kuningan kepada generasi muda, salah satunya dengan menggelar festival-festival alat musik tradisional. Namun, upaya tersebut belum mebuahkan hasil yang optimal karena keterbatasan frekuensi pelaksanaan kegiatan yang hanya satu tahun sekali dan keterbatasan jumlah alat-alat musik tradisonal yang ada. Selain itu, banyak masyarakat yang belum mengetahui informasi dari alat musik tradisional yang ada di Kabupaten Kuningan tersebut, terutama mengenai sejarah dan cara memainkan alat musik tradisional tersebut dengan baik dan benar. Hal lain yang menjadi kendala sulitnya masyarakat untuk mengetahu, memahami dan menggali alat musik tradisional kuningan antara lain harga yang cukup mahal dan keberadaan lokasi alat musik yang cukup jauh dari jangkauan, sehingga sebagian besar masyarakat hanya dapat menonton dan mendengarkannya lewat televisi, radio, internet, ataupun festival alat musik tradisional yang hanya digelar sekali dalam satu tahun. Maka dari itu diperlukan suatu teknologi alternatif yang mampu memberikan informasi dari alat musik tradisional, bersifat menarik dan interaktif.

Seiring berkembangnya zaman, banyak teknologi yang berkembang saat ini, salah satunya Augmented Reality atau lebih dikenal dengan AR. Pembuatan aplikasi ini bertujuan untuk memberikan informasi kepada masyarakat, khususnya pemuda tentang alat musik tradisional yang ada di Kabupaten Kuningan sebagai sarana media yang lebih menarik dengan adanya objek 3D dan juga dilengkapi dengan adanya media vidio dan audio pada objek 3D tersebut.[1]

\section{METODOLOGI PENELITIAN}

a. Metode Pengumpulan Data

Metode pengumpulan data yang digunakan yang digunakan oleh penulis adalah :

1. Kepustakaan 
JURNAL NUANSA INFORMATIKA

Volume 15 Nomor 1, Januari 2021

Memilih jurnal dan buku referensi yang sesuai dengan permasalahan penelitian, sehingga dengan mencari informasi dari beberapa sumbersumber seperti buku, jurnal, paper dan situs internet. Sumber-sumber ini digunakan untuk melengkapi data-data dan informasi yang dibutuhkan dalam penelitian.

2. Observasi

Datang langsung ke tempat lokasi Dinas Pendidikan dan Kebudayaan Kabupaten Kuningan untuk mengamati situasi serta kondisi yang sedang berjalan saat ini. Hal tersebut dilakukan untuk mendapatkan data secara langsung pada objek yang diteliti sebagai bahan penelitian.

3. Wawancara

Melakukan wawancara dengan bapak Edi Kusnadi, S.Sn sebagai Kepala Seksi Kebudayaan, Dalam hal ini diperlukan guna untuk mencari kelengkapan dan kebenaran data.

b. Metode penyelesaian masalah

1. Augmented Reality (AR)

Augmented Reality adalah kombinasi antara dunia maya (virtual) dan dunia nyata yang dibuat oleh komputer. Obyek virtual dapat berupa teks, animasi, model $3 \mathrm{D}$, atau video yang digabungkan dengan lingkungan sebenarnya sehingga pengguna merasakan obyek virtual seolah informasi tersbeut nyata.

Pembuatan sistem Augmented Reality membutuhkan :

1. Model 3D dari objek untuk digabungkan dengan dunia nyata.

2. Korespodensi antara dunia nyata dengan model 3D melalui kalibrasi.
p-ISSN : 1858-3911, e-ISSN : 2614-5405

https://journal.uniku.ac.id/index.php/ilkom

3. Tracking digunakan menentukan sudut pandangan pengguna terhadap dunia nyata.

4. Real-Time Display yang digabungkan dengan citra asli dan juga grafik komputer yang dibuat berdasarkan model.

5. Waktu respon terhadap gerakan dan akurasi antara gambar dan grafik sangat mempengaruhi keefektifan sistem.

\section{FAST Corner Detector}

FAST Corner Detector adalah suatu algoritma yang dikembangkan oleh Edward Rosten dan Tom Drummond. FAST Corner Detector ini dibuat dengan tujuan mempercepat waktu komputasi secara real-time dengan konsekuensi menurunkan tingkat akurasi pendeteksian sudut [2] FAST Corner Detector merupakan algoritma pendeteksi interest point (titik minat) dengan kecepatan tinggi berdasarkan pertimbangan pixel dalam area melingkar disekitar interest point (titik minat). Interest point detection (deteksi titik minat) adalah suatu pendekatan yang digunakan dalam visi komputer sistem dan proses segmentasi untuk mengambil beberapa sudut dari suatu objek dan menyimpulkan isi dari suatu images.

Deteksi sudut sering digunakan dalam mendeteksi gerakan, pencocokan gambar, pelacakan, 3D modelling, dan pengenalan objek.[4] Sebuah sudut didefinisikan sebagai perpotongan dua sisi. Sebuah sudut juga dapat didefinisikan sebagai titik yang memiliki dua sisi dominan dan berbeda arah dari titik tersebut. Sebuah titik minat adalah sebuah titik yang terdapat pada images yang posisinya telah ditentukan dengan 
JURNAL NUANSA INFORMATIKA

Volume 15 Nomor 1, Januari 2021

baik dan dapat terdeteksi dengan baik. Ini bearti bahwa titik minat bias menjadi titik sudut tetapi juga dapat menjadi titik minat yang sebenarnya.

Berikut ini adalah cara kerja beserta contoh kasus algoritma FAST (Features From Accelerated Segment Test) Corner Detector :

1. Tentukan sebuah titik $p$ pada citra tersebut dengan posisi awal $\left(\mathrm{x}_{\mathrm{p}}, \mathrm{y}_{\mathrm{p}}\right)$.

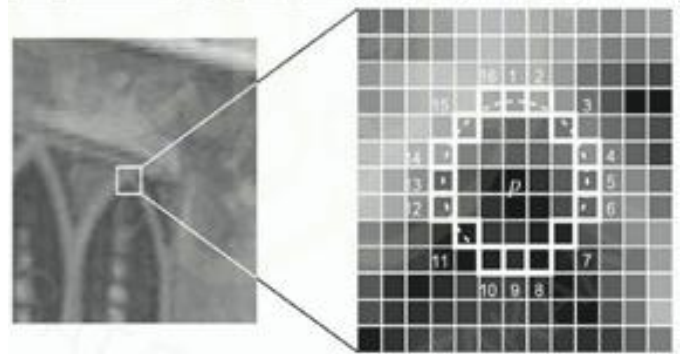

Gambar 1 Titik awal yang diuji ${ }^{[2]}$

2. Tentukan keempat titik. Titik pertama $(n=1)$ terletak pada koordinat $\left(\mathrm{x}_{\mathrm{p}}, \mathrm{y}_{\mathrm{p}+3}\right)$, titik kedua $(n=$ 2) terletak pada koordinat $\left(x_{p+3}, y_{p}\right)$, titik ketiga terletak pada koordinat $(n=3)$ terletak pada koordinat $\left(\mathrm{x}_{\mathrm{p}}\right.$, yp-3), titik keempat $(n=4)$ terletak pada koordinat $\left(\mathrm{x}_{\mathrm{p}-3}, \mathrm{y}_{\mathrm{p}}\right)$.
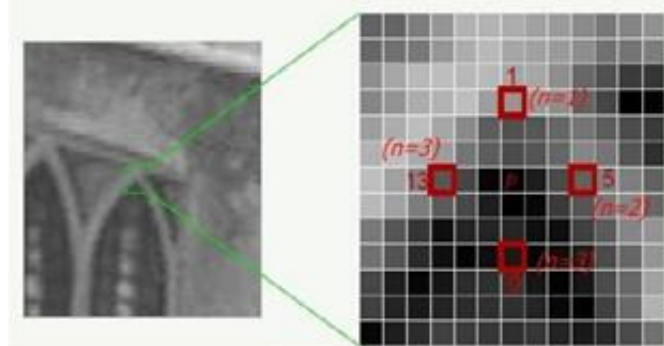

Gambar 2 Keempat titik koordinat ${ }^{[2]}$

3. Bandingkan intensitas titik pusat $p$ dengan keempat titik disekitar. Jika terdapat paling sedikit 3 titik yang memenuhi syarat berikut, maka titik pusat $\mathrm{p}$ adalah titik sudut.

$S p-x=$

$\begin{cases}I p-x \leq I p-t & \text { (darker) } \\ I p-t<I p-x<I p+t & \text { (similiar) } \\ I p+t \leq I p-x & \text { (brighter) }\end{cases}$

Keterangan :
p-ISSN : 1858-3911, e-ISSN : 2614-5405

https://journal.uniku.ac.id/index.php/ilkom

Ip = intensitas pixel

$t=$ treshold

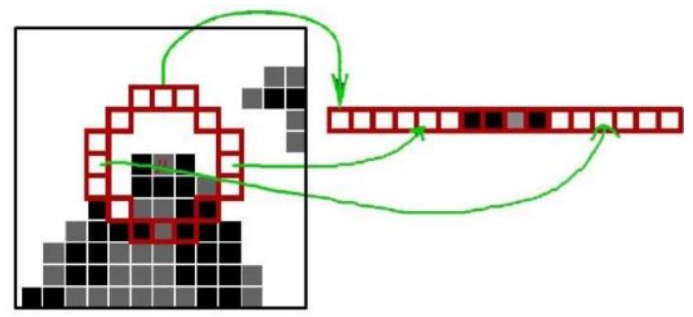

Gambar 3 Tiga titik yang memenuhi syarat $^{[2]}$

4. Ulangi proses sampai seluruh titik pada citra sudah dibandingkan intensitasnya.

c. Metode Pengembangan sistem

Metode pengembangan sistem yang digunakan penulis dalam penelitian ini adalah Rational Unified Proses (RUP). Rational Unified Pocesss (RUP) adalah pendekatan perangkat lunak yang dilakukan berulang-ulang (iterative), fokus pada arsitektur (architecturecentrik), lebih diarahkan berdasarkan penggunaan kasus (use case driven). Dapat dilihat pada Gambar 4

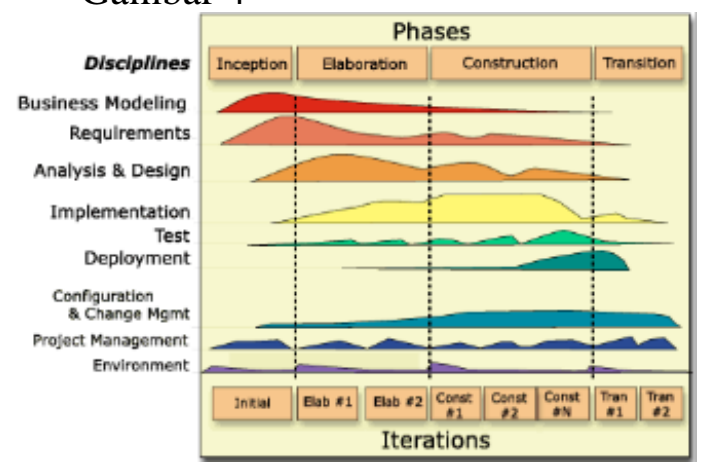

Gambar 4 Model RUP ${ }^{[3]}$

(Sumber : Suryana, 2007)

Pada Gambar diatas menjelaskan bahwa RUP memiliki empat tahapan atau fase yang dapat dilakukan pula secara iterative, yaitu tahap Inception, Elaboration, Construction dan Transition.

\section{d. Perancangan Sistem}


JURNAL NUANSA INFORMATIKA

Volume 15 Nomor 1, Januari 2021

Perancangan sistem adalah merancang atau mendesai suatu sistem yang baik. Perancangan sistem bertujuan untuk mendapatkan gambaran dengan jelas tentang apa yang dikerjakan sistem.

1. Use Case Diagram

Use case merupakan gambaran skenario dari interaksi antara user dengan sistem. Sebuah diagram use case menggambarkan hubungan antara aktor dan kegiatan yang dapat dilakukannya terhadap aplikasi.

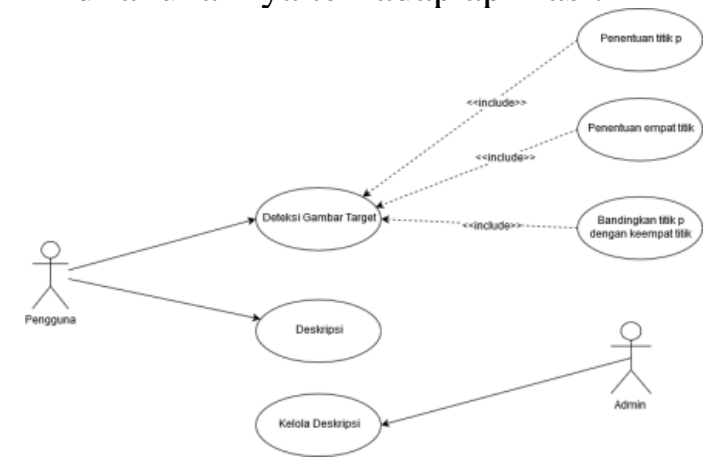

Gambar 5 . Use Case Diagram

2. Skenario Use Case Deteksi Gambar Target

Use case deteksi gambar target ini menggambarkan proses dimana sistem mulai mendeteksi gambar target pada aplikasi augmented reality pada pengenalan alat musik tradisional yang ada di Kabupaten Kuningan ini.

Tabel 1 Skenario Use Case Deteksi Gambar Target

\begin{tabular}{|l|l|}
\hline \multicolumn{2}{|c|}{ Identifikasi } \\
\hline ID Use Case & PASIRANGAR-01 \\
\hline $\begin{array}{l}\text { Nama Use } \\
\text { Case }\end{array}$ & $\begin{array}{l}\text { Deteksi Gambar } \\
\text { target }\end{array}$ \\
\hline Tujuan & $\begin{array}{l}\text { Menampilkan } \\
\text { objek 3D melalui } \\
\text { gambar target yang } \\
\text { ditangkap oleh } \\
\text { kamera. }\end{array}$ \\
\hline \multicolumn{2}{|c|}{ Deskripsi } \\
\hline
\end{tabular}

p-ISSN : 1858-3911, e-ISSN : 2614-5405 https://journal.uniku.ac.id/index.php/ilkom

\begin{tabular}{|c|c|}
\hline Prioritas & Primary \\
\hline Aktor & Pengguna \\
\hline \multicolumn{2}{|c|}{ Skenario Utama } \\
\hline $\begin{array}{l}\text { Pre } \\
\text { Condition }\end{array}$ & 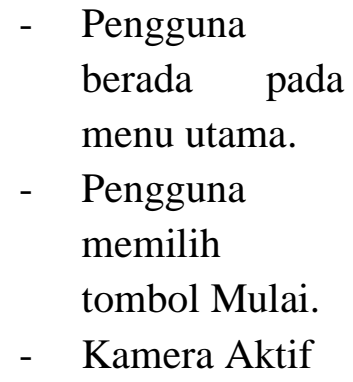 \\
\hline Aksi Aktor & Reaksi Sistem \\
\hline $\begin{array}{l}\text { 1. Pengguna } \\
\text { mengarah } \\
\text { kan } \\
\text { kamera ke } \\
\text { gambar } \\
\text { target } \\
\text { yang } \\
\text { benar. }\end{array}$ & 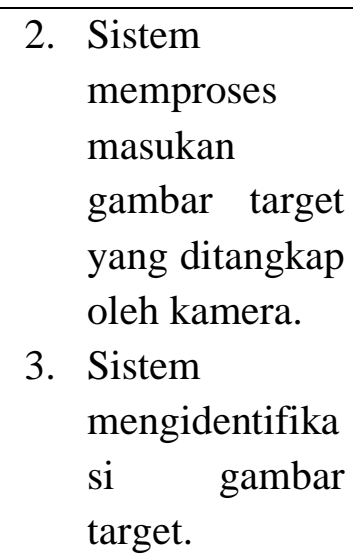 \\
\hline $\begin{array}{l}\text { Post } \\
\text { Condition }\end{array}$ & $\begin{array}{l}\text { Jika gambar target } \\
\text { berhasil } \\
\text { teridentifikasi/dapa } \\
\text { t dikenali, maka } \\
\text { sistem } \\
\text { menampilkan objek } \\
\text { 3D berupa alat } \\
\text { musik tradisional } \\
\text { yang ada di } \\
\text { Kabupaten } \\
\text { Kuningan beserta } \\
\text { tombol } \\
\text { "Informasi". } \\
\text { Tetapi Jika gambar } \\
\text { target tidak berhasil } \\
\text { teridentifikasi/dapa } \\
\text { t dikenali, maka } \\
\text { sistem men } \\
\text { menampilkan } \\
\text { pesan "marker } \\
\text { tidak terdeteksi" } \\
\text { dan pengguna } \\
\text { harus kembali }\end{array}$ \\
\hline
\end{tabular}


JURNAL NUANSA INFORMATIKA

Volume 15 Nomor 1, Januari 2021

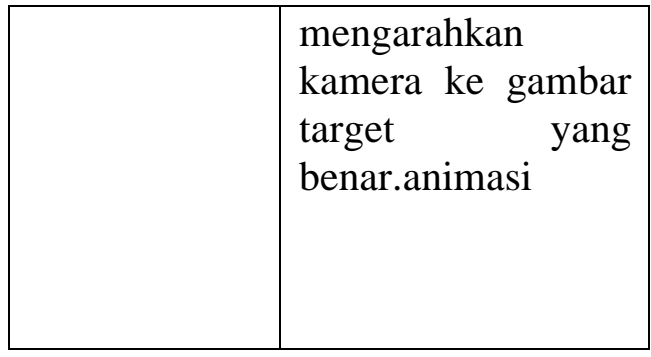

3. Skenario Use Case Deskripsi

Use case deskripsi ini menggambarkan proses dimana sistem mulai menampilkan deskripsi objek 3D yang muncul melalui gambar target.

Tabel 2 Skenario Use Case Deskripsi

\begin{tabular}{|c|c|}
\hline \multicolumn{2}{|c|}{ Identifikasi } \\
\hline ID Use Case & $\begin{array}{l}\text { PASIRANGAR- } \\
02\end{array}$ \\
\hline $\begin{array}{l}\text { Nama Use } \\
\text { Case }\end{array}$ & Deskripsi \\
\hline Tujuan & $\begin{array}{l}\text { Menampilkan } \\
\text { deskripsi } \\
\text { mengenai alat } \\
\text { musik tradisional } \\
\text { yang ada di } \\
\text { Kabupaten } \\
\text { Kuningan. }\end{array}$ \\
\hline \multicolumn{2}{|c|}{ Deskripsi } \\
\hline Prioritas & Primary \\
\hline Aktor & Pengguna \\
\hline \multicolumn{2}{|c|}{ Skenario Utama } \\
\hline Pre Condition & $\begin{array}{l}\text { - } \text { Internet } \\
\text { harus dalam } \\
\text { keadaan } \\
\text { online. } \\
\text { - Pengguna } \\
\text { berada pada } \\
\text { menu } \\
\text { Informasi. }\end{array}$ \\
\hline Aksi Aktor & Reaksi Sistem \\
\hline $\begin{array}{l}\text { 1. Pengguna } \\
\text { memilih } \\
\text { area nama } \\
\text { alat musik }\end{array}$ & $\begin{array}{l}\text { 2. Sistem } \\
\text { mengambil } \\
\text { data deskripsi } \\
\text { alat musik }\end{array}$ \\
\hline
\end{tabular}

p-ISSN : 1858-3911, e-ISSN : 2614-5405 https://journal.uniku.ac.id/index.php/ilkom

\begin{tabular}{|c|c|}
\hline $\begin{array}{l}\text { tradisional } \\
\text { tersebut. }\end{array}$ & $\begin{array}{l}\text { tradisional } \\
\text { dari kolom } \\
\text { deskripsi pada } \\
\text { tabel } \\
\text { deskripsi. }\end{array}$ \\
\hline Post Condition & 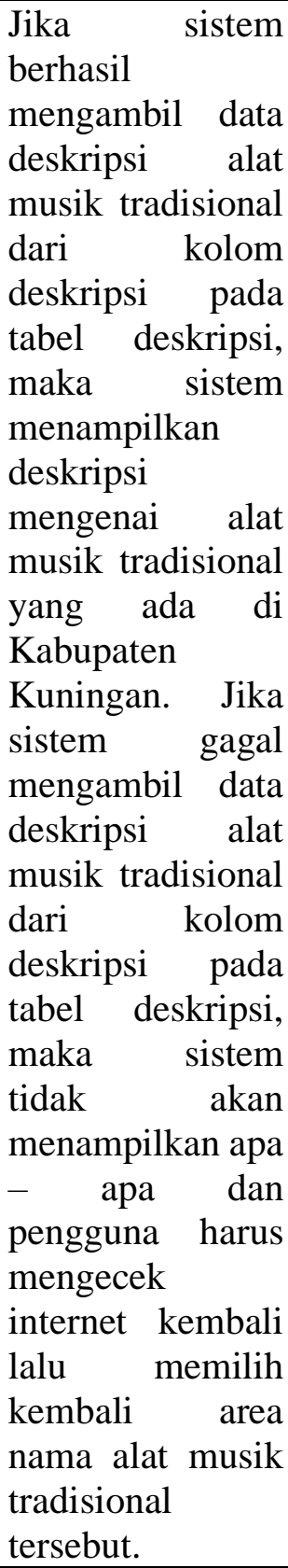 \\
\hline
\end{tabular}

4. Skenario Use Case Kelola Deskripsi

Use case kelola deskripsi ini menggambarkan proses dimana sistem mengelola tabel deskripsi dari basis data. 
JURNAL NUANSA INFORMATIKA

Volume 15 Nomor 1, Januari 2021

Tabel 3 Skenario Use Case Kelola Deskripsi

\begin{tabular}{|c|c|}
\hline \multicolumn{2}{|c|}{ Identifikasi } \\
\hline ID Use Case & $\begin{array}{l}\text { PASIRANGAR- } \\
03\end{array}$ \\
\hline Nama Use Case & Kelola Deskripsi \\
\hline Tujuan & $\begin{array}{lr}\text { Mengelola } & \text { tabel } \\
\text { deskripsi } & \text { dari } \\
\text { basis data. } & \\
\end{array}$ \\
\hline \multicolumn{2}{|c|}{ Deskripsi } \\
\hline Prioritas & Primary \\
\hline Aktor & Admin \\
\hline \multicolumn{2}{|c|}{ Skenario Utama } \\
\hline Pre Condition & 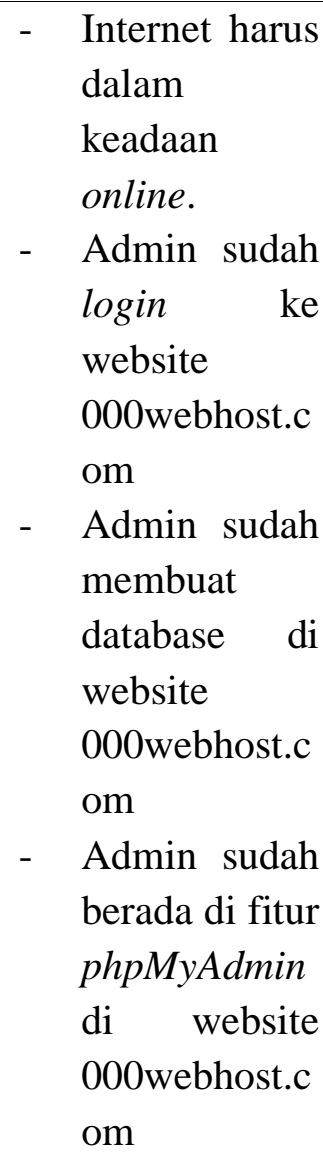 \\
\hline Aksi Aktor & Reaksi Sistem \\
\hline $\begin{array}{l}\text { 1. Admin } \\
\text { memilih } \\
\text { basis data } \\
\text { Pasirangar. }\end{array}$ & $\begin{array}{l}\text { 2. Sistem } \\
\text { menampilkan } \\
\text { tabel }- \text { tabel } \\
\text { yang ada } \\
\text { didalam basis } \\
\text { data } \\
\text { Pasirangar. }\end{array}$ \\
\hline $\begin{array}{l}\text { 3. Admin } \\
\text { memilih }\end{array}$ & $\begin{array}{l}\text { 4. Sistem } \\
\text { menampilkan }\end{array}$ \\
\hline
\end{tabular}

p-ISSN : 1858-3911, e-ISSN : 2614-5405 https://journal.uniku.ac.id/index.php/ilkom

\begin{tabular}{|c|c|}
\hline $\begin{array}{l}\text { tabel } \\
\text { deskripsi. }\end{array}$ & $\begin{array}{lr}\text { data }- \text { data } \\
\text { yang } & \text { ada } \\
\text { didalam tabel } \\
\text { deskripsi. }\end{array}$ \\
\hline $\begin{array}{l}\text { 5. Admin } \\
\text { memilih } \\
\text { salah satu } \\
\text { deskripsi alat } \\
\text { musik } \\
\text { tradisional } \\
\text { dari kolom } \\
\text { deskripsi. }\end{array}$ & $\begin{array}{l}\text { 6. Sistem akan } \\
\text { menampilkan } \\
\text { isi deskripsi } \\
\text { alat musik } \\
\text { tradisional } \\
\text { tersebut. }\end{array}$ \\
\hline $\begin{array}{l}\text { 7. Admin } \\
\text { menambahka } \\
\text { n/mengubah } \\
\text { isi deskripsi } \\
\text { alat musik } \\
\text { tradisional } \\
\text { tersebut. }\end{array}$ & \\
\hline Post Condition & $\begin{array}{l}\text { Sistem } \\
\text { menampilkan isi } \\
\text { deskripsi alat } \\
\text { musik tradisional } \\
\text { tersebut dari tabel } \\
\text { deskripsi. }\end{array}$ \\
\hline
\end{tabular}

\section{Activity Diagram}

Activity diagram menggambarkan berbagai aliran aktivitas dalam sistem yang sedang dirancang, bagaimana masing-masing aliran berawal, desicion yang mungkin terjadi, dan bagaimana suatu aktivitas berakhir.

- Activity Diagram Deteksi Gambar Target.

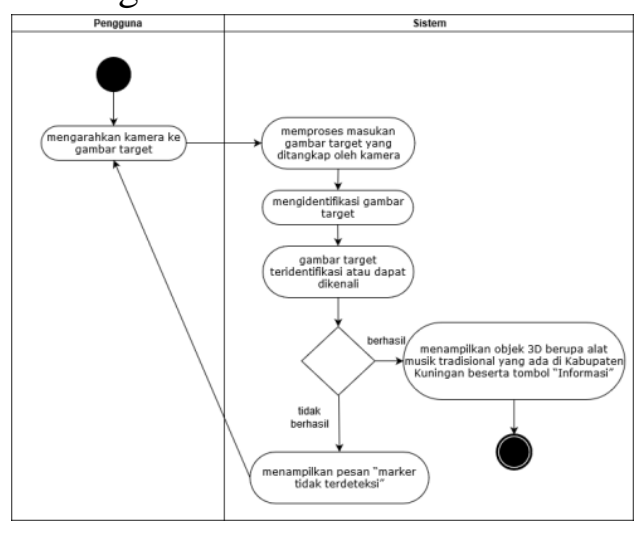


JURNAL NUANSA INFORMATIKA

Volume 15 Nomor 1, Januari 2021

Gambar 6 Activity Diagram

Deteksi Gambar Target.

- Activity Diagram Deskripsi

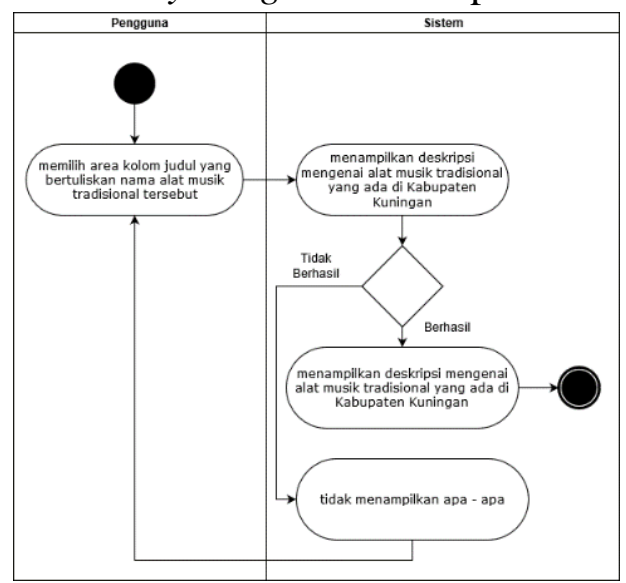

Gambar 7 Activity Diagram Deskripsi

- Activity Diagram Kelola Deskripsi

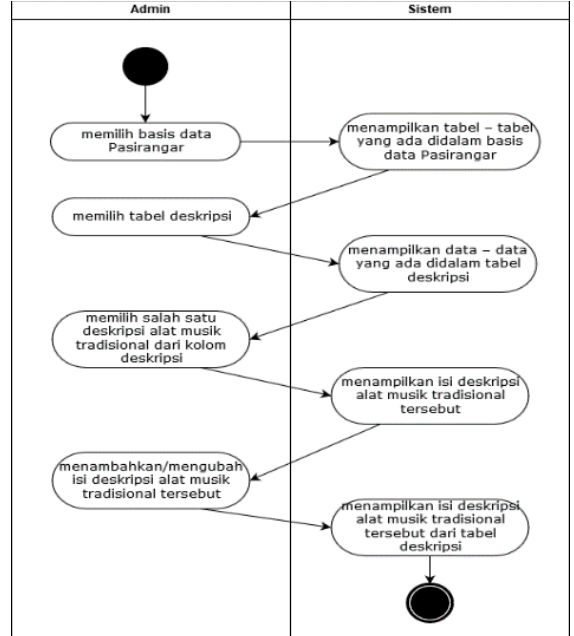

Gambar 8 Activity Diagram Kelola Deskripsi

6. Sequence Diagram

Diagram ini menunjukan interaksi yang terjadi antara objek. Diagram sekuensial ini merupakan pandangan dinamis terhadap sistem. Diagram ini menekankan pada basis keberurutan waktu dari pesan-pesan yang terjadi.
p-ISSN : 1858-3911, e-ISSN : 2614-5405

https://journal.uniku.ac.id/index.php/ilkom

- Sequence Diagram Deteksi Gambar Target

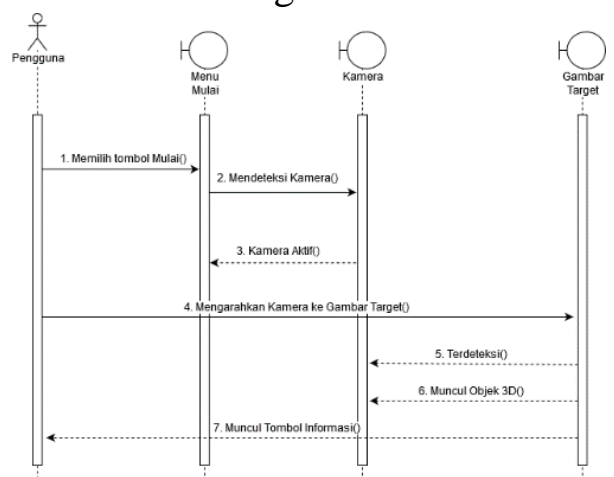

Gambar 9 Sequence diagram Deteksi Gambar Target

- Sequence Diagram Deskripsi

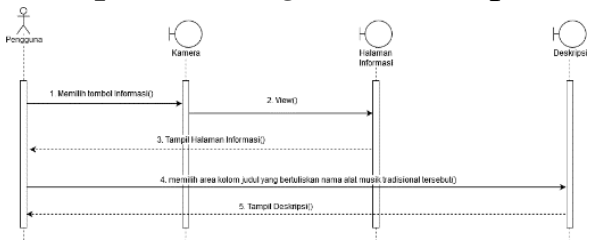

Gambar 10 Sequence Diagram Deskripsi

- Sequence Diagram Kelola Deskripsi

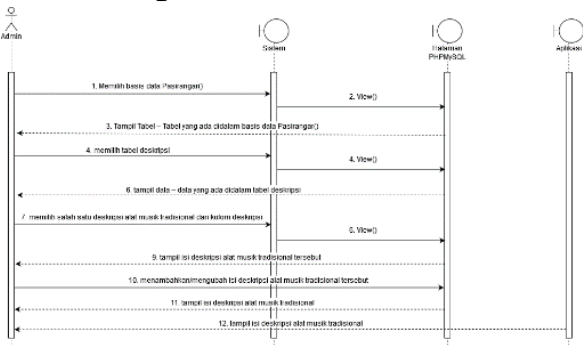

Gambar 11 Sequence Diagram Kelola Deskripsi 
JURNAL NUANSA INFORMATIKA

Volume 15 Nomor 1, Januari 2021

\section{HASIL DAN PEMBAHASAN}

Hasil dari penelitian ini berupa aplikasi yang siap digunakan oleh user. Antarmuka merupakan tampilan yang akan digunakan oleh user dalam menjalankan aplikasi yang akan digunakan oleh user dalam menjalankan aplikasi augmented reality pada pengenalan alat musik tradisional yang ada di Kabupaten Kuningan. Berikut ini adalah beberapa halaman antarmuka aplikasi yang telah dibangun :

- Tampilan Menu Utama

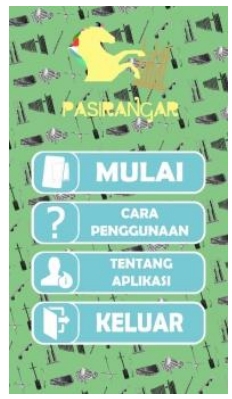

Gambar 12 Tampilan Menu Utama Aplikasi

Pada menu utama ini terdapat beberapa menu yang ditampilkan didalam aplikasi, yaitu : menu Mulai, menu Cara Penggunaan, menu Tentang Aplikasi, dan menu Keluar.

- Tampilan Menu Mulai

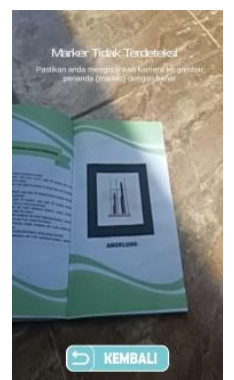

Gambar 13 Tampilan Menu Mulai

Gambar 13 merupakan tampilan menu mulai. Halaman menu Mulai ini berfungsi untuk mendeteksi marker serta menampilkan output dari aplikasi augmented reality ini yaitu berupa objek 3D alat musik
p-ISSN : 1858-3911, e-ISSN : 2614-5405 https://journal.uniku.ac.id/index.php/ilkom

tradisional yang ada di Kabupaten Kuningan. Pada halaman tersebut, terdapat tombol Kembali untuk kembali ke halaman menu utama dan tombol Informasi untuk menampilkan informasi mengenai objek 3D tersebut sesuai penanda (marker). Tombol Informasi ini muncul apabila objek 3D tersebut berhasil dideteksi.

Pada gambar 14 dibawah ini merupakan tampilan hasil output dari pendeteksian salah satu penanda (marker).

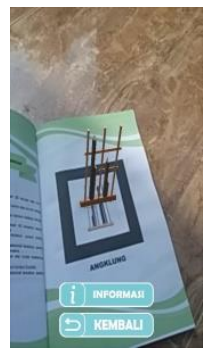

Gambar 14 Hasil output dari pendeteksian salah satu penanda (marker) pada tampilan Menu Mulai

- Tampilan Menu Informasi

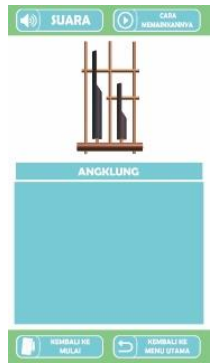

Gambar 15 Tampilan Menu Informasi

Gambar 15 merupakan tampilan menu informasi. Pengguna akan melihat informasi mengenai salah satu objek 3D alat musik tradisional yang ada di Kabupaten Kuningan berupa teks deskripsi, audio, dan video sesuai penanda (marker) yang berhasil dideteksi pada menu Mulai. Pada halaman menu Informasi ini terdapat 5 tombol, yaitu :

a. Area nama objek 3D tersebut : menampilkan teks deskripsi mengenai objek 3D tersebut. Teks deskripsi itu 
JURNAL NUANSA INFORMATIKA

Volume 15 Nomor 1, Januari 2021

muncul apabila internet sedang dalam keadaan terhubung (online).

b. Suara : untuk mendengarkan suara (audio) objek 3D tersebut. Untuk berhenti mendengarkan suara (audio) objek 3D tersebut, pilih tombol Suara sekali lagi.

c. Cara Memainkannya : untuk menampilkan dan memutar vidio (video) mengenai cara memainkan objek 3D tersebut. Vidio tersebut berjalan dengan lancar pada saat diputar apabila internet sedang dalam keadaan terhubung (online).

d. Kembali Ke Mulai : untuk kembali ke halaman menu Mulai.

e. Kembali Ke Menu Utama : untuk kembali ke halaman menu utama.

Pada gambar 16 dibawah ini merupakan tampilan teks deskripsi mengenai salah satu objek 3D tersebut apabila pengguna memilih tombol area nama objek 3D tersebut.

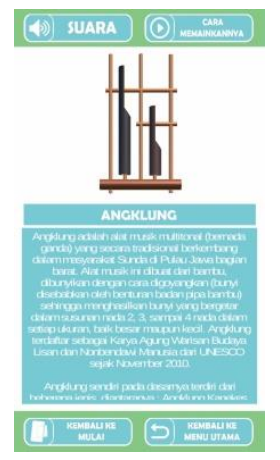

Gambar 16 Tampilan teks deskripsi pada Menu Informasi

Pada gambar 17 dibawah ini merupakan tampilan vidio mengenai cara memainkan objek 3D tersebut apabila pengguna memilih tombol Cara Memainkannya.
p-ISSN : 1858-3911, e-ISSN : 2614-5405

https://journal.uniku.ac.id/index.php/ilkom

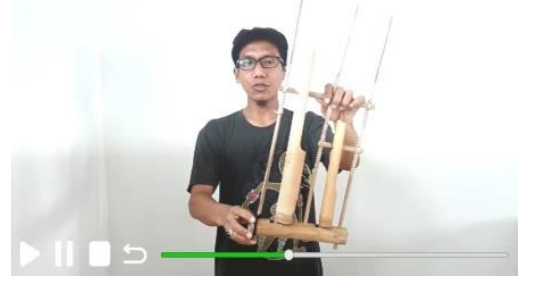

Gambar 17 Tampilan teks deskripsi pada Menu Informasi

- Tampilan Menu Cara Penggunaan

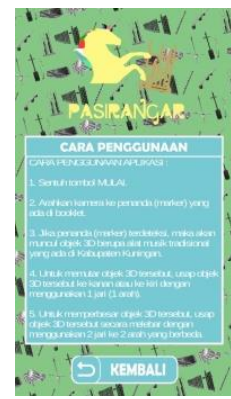

Gambar 18 Tampilan Menu Cara

Penggunaan

Gambar 18 merupakan menu untuk menampilkan cara penggunaan dari aplikasi augmented reality pada pengenalan alat musik tradisional yang ada di Kabupaten Kuningan.

- Tampilan Menu Tentang Aplikasi

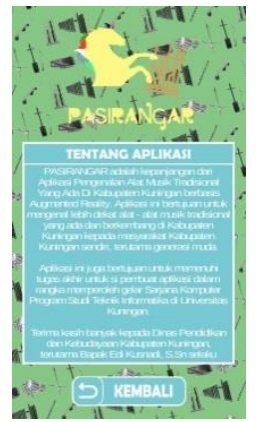

Gambar 19 Tampilan Menu Tentang Aplikasi

Gambar 19 merupakan menu untuk menampilkan informasi mengenai aplikasi augmented reality pada pengenalan alat musik tradisional yang ada di Kabupaten Kuningan.

- Tampilan Menu Keluar 
JURNAL NUANSA INFORMATIKA

Volume 15 Nomor 1, Januari 2021

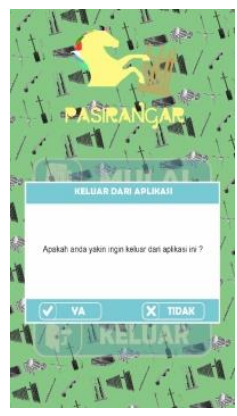

Gambar 20 Tampilan Menu Keluar

Gambar 20 merupakan tampilan konfirmasi ketika pengguna menekan tombol keluar pada menu utama.

Aplikasi dibuat dengan tampilan sederhana, yang bertujuan untuk mempermudah user dalam mengoprasikan aplikasi augmented reality pada pengenalan alat musik tradisional yang ada di Kabupaten Kuningan.

Jarak kamera dengan marker dan intensitas cahaya memiliki pengaruh terhadap hasil AR [5].

Tabel 4 Hasil Pengujian Pengaruh Intensitas Cahaya

\begin{tabular}{|c|c|c|c|}
\hline \multirow{2}{*}{ No. } & \multirow{2}{*}{ Kondisi } & \multicolumn{2}{|c|}{ Hasil Pengujian } \\
\hline & & Gambar & Keterangan \\
\hline 1. & $\begin{array}{l}\text { Siang } \\
\text { diluar } \\
\text { ruangan }\end{array}$ & & $\begin{array}{l}\text { Marker } \\
\text { terdeteksi, } \\
\text { objek } 3 D \\
\text { dapat } \\
\text { ditampilkan } \\
\text { dengan baik. }\end{array}$ \\
\hline 2. & $\begin{array}{l}\text { Siang } \\
\text { didalam } \\
\text { ruangan } \\
\text { tanpa } \\
\text { lampu } \\
\text { (sedikit } \\
\text { cahaya) }\end{array}$ & & $\begin{array}{l}\text { Marker } \\
\text { terdeteksi, } \\
\text { objek } 3 \mathrm{D} \\
\text { dapat } \\
\text { ditampilkan } \\
\text { dengan baik. }\end{array}$ \\
\hline 3. & $\begin{array}{l}\text { Malam } \\
\text { mengguna } \\
\text { kan } \\
\text { lampu }\end{array}$ & 111 & $\begin{array}{l}\text { Marker } \\
\text { terdeteksi, } \\
\text { objek } 3 \mathrm{D} \\
\text { dapat } \\
\text { ditampilkan } \\
\text { dengan baik. }\end{array}$ \\
\hline 4. & $\begin{array}{l}\text { Malam } \\
\text { tanpa } \\
\text { lampu }\end{array}$ & & $\begin{array}{l}\text { Marker tidak } \\
\text { terdeteksi, } \\
\text { objek } 3 \mathrm{D} \\
\text { tidak dapat } \\
\text { ditampilkan } \\
\text { karena tidak } \\
\text { ada cahaya. }\end{array}$ \\
\hline
\end{tabular}

p-ISSN : 1858-3911, e-ISSN : 2614-5405

https://journal.uniku.ac.id/index.php/ilkom

Tabel 5 Hasil Pengujian Jarak Kamera Dengan Marker

\begin{tabular}{|c|c|c|c|}
\hline \multirow{2}{*}{ No. } & \multirow{2}{*}{ Jarak } & \multicolumn{2}{|c|}{ Hasil Pengujian } \\
\hline & & Gambar & Keteangan \\
\hline 1. & $4 \mathrm{~cm}$ & & $\begin{array}{l}\text { Marker } \\
\text { terdeteksi, } \\
\text { tampil objek } \\
\text { 3D }\end{array}$ \\
\hline 2. & $6 \mathrm{~cm}$ & & $\begin{array}{l}\text { Marker } \\
\text { terdeteksi, } \\
\text { tampil objek } \\
\text { 3D }\end{array}$ \\
\hline 3. & $10 \mathrm{~cm}$ & & $\begin{array}{l}\text { Marker } \\
\text { terdeteksi, } \\
\text { tampil objek } \\
\text { 3D }\end{array}$ \\
\hline 4. & $15 \mathrm{~cm}$ & & $\begin{array}{l}\text { Marker } \\
\text { terdeteksi, } \\
\text { tampil objek } \\
\text { 3D }\end{array}$ \\
\hline 5. & $20 \mathrm{~cm}$ & & $\begin{array}{l}\text { Marker } \\
\text { terdeteksi, } \\
\text { tampil objek } \\
\text { 3D }\end{array}$ \\
\hline 6. & $21 \mathrm{~cm}$ & & $\begin{array}{l}\text { Marker tidak } \\
\text { terdeteksi, } \\
\text { tidak tampil } \\
\text { objek 3D }\end{array}$ \\
\hline
\end{tabular}


JURNAL NUANSA INFORMATIKA

Volume 15 Nomor 1, Januari 2021

\section{KESIMPULAN}

Berdasarkan hasil penelitian yang telah dilakukan, maka dapat diperoleh simpulan sebagai berikut :

1. Aplikasi ini dapat memudah masyarakat untuk mengetahui informasi mengenai alat musik tradisional yang ada di Kabupaten Kuningan.

2. Informasi yang diberikan menjadi lebih efektif dan interaktif dengan adanya teknologi Augmented Reality dan dengan adanya objek 3D berupa Alat Musik Tradisional yang ada di Kabupaten Kuningan, penyampaian secara visualisasi menjadi lebih menarik.

\section{SARAN}

Berdasarkan hasil penelitian yang telah dilakukan, maka penulis merekomendasikan beberapa saran untuk diterapkan pada penelitian selanjutnya. Adapun saran-saran dari penulis yaitu :

1. Aplikasi ini diharapkan untuk ada penelitian lanjutan sehingga aplikasi ini dapat dikembangkan lagi ke platform lainnya, seperti iOS (iphone).

2. Diharapkan untuk ada pengembangan terhadap objek 3D yang dibuat untuk dapat lebih baik lagi sehingga menyerupai bentuk aslinya.

3. Diharapkan pula untuk ada penambahan terhadap objek 3D alat musik tradisional yang ada di Kabupaten Kuningan berserta deskripsi, audio, dan vidio cara memainkannya, sehingga masyarakat dapat mengetahui pula alat - alat musik tradisonal yang ada di Kabupaten Kuningan yang lainnya.
p-ISSN : 1858-3911, e-ISSN : 2614-5405

https://journal.uniku.ac.id/index.php/ilkom

\section{DAFTAR PUSTAKA}

[1] Arifitama, Budi. 2017. Panduan Mudah Membuat Augmented Reality. Yogyakarta : Andi Publisher.

[2] Irsyad, Mohammad Syahrofi. 2016. Aplikasi Augmented Reality Sebagai Media Simulasi Ikatan Kimia Berbasis Android Menggunakan Metode FAST Corner Detection. Malang : Program Studi Teknik Informatika, Universitas Maulana Malik Ibrahim Malang.

[3] Suryana, Taryana. 2007. Metode RUP. Tugas Makalah Ilmiah. STMIK LIKMI. Bandung.

[4] Zhou,F., Duh,H,B,L. \& Billinghurst,M., (2008) Trends in Augmented Reality Tracking, Interaction and Display: A Review of Ten Years of ISMAR. IEEE and ACM ISMAR 2008 (pp. 193-202). Cambridge, UK: IEEE and ACM

[5] Priantama, Rio. 2020. Implementasi Algoritma SIFT Pada Aplikasi Media Pembelajaran Pendidikan Anak Usia Dini (PAUD) Berbasis Augmented Reality Melalui Android. Buffer Informatika. Vol 6, No.2 (2020) Hal . 37 - 46 